\title{
Ascertaining the Discursive Construction of the Cosmopolitan Identity: An Analysis of Bharati Mukherjee's Jasmine
}

\author{
Zia Ullah ${ }^{1}$, Wajid Hussain ${ }^{2} \&$ Anayat Ullah $^{3}$ \\ ${ }^{1}$ Lecturer in English, Department of English Literature \& Linguistics, Shaheed Benazir Bhutto University, \\ Sheringal, Upper Dir, KPK, Pakistan \\ ${ }^{2}$ Faculty Social Sciences, Shaheed Zulfikar Ali Bhutto Institute of Science \& Technology (SZABIST), \\ Islamabad, Pakistan \\ ${ }^{3}$ Lecturer in English, Department of English Literature \& Linguistics, Shaheed Benazir Bhutto University, \\ Sheringal, Upper Dir, KPK, Pakistan \\ Correspondence: Zia Ullah, Department of English Literature \& Linguistics at Shaheed Benazir Bhutto \\ University, Sheringal, Upper Dir, KPK, Pakistan. E-mail: ziastella77@yahoo.com
}

\author{
Received: August 1, 2019 Accepted: August 26, 2019 Online Published: September 11, 2019 \\ doi:10.5539/ijel.v9n5p392 URL: https://doi.org/10.5539/ijel.v9n5p392
}

\begin{abstract}
This paper anatomizes Bharati Mukherjee's Jasmine in the perspective of cultural assimilation and determines the extent of establishing cosmopolitan identity through discourse. The researcher uses the theoretical framework propounded by Appiah to examine the contribution and representation of literary globalization in the making of 'universal citizen' whose cultural and geographical boundary crossing results into the formation of post-modern fluid identities. Methodologically, this qualitative content analysis uses the joint venture of Appiah's concept of cosmopolitanism and Fairclough's notion of naturalization focusing on three scenarios which specify an acceptance of differences, accentuation of differences, and attempt to resolve the differences. The analysis reflects that boundary crossing by the immigrants has formed fluidity and has given exponential boost to the idea of harmony and coexistence. It also reveals that this transformation of identity owes to the discourse of the dominant culture which reshapes fundamental knowledge and values for the individuals of minorities. However, it also signifies that postmodern cosmopolitan fluidity continues to thrive.
\end{abstract}

Keywords: cosmopolitanism, postmodern, fluidity, discourse

\section{Introduction}

In today's technologically advanced and globalized world, living in harmony, coexistence, and peace with others is impossible. Cosmopolitanism illustrates the idea of mutual respect and cultural adaptation. Encyclopedia Britannica explicates the term cosmopolitanism as a notion that all people deserve equal rights, consideration, and veneration irrespective of their backgrounds (Brock, 2015, p. 113). Cosmopolitan ideology clarifies that human groups belong to a single universal community. Bohman and Lutz comment, it is the moral obligation of world citizen to drag the spheres by some means towards the centre which make all human beings our fellow city denizens (1997, p. 33).

Culture, for its constitution, owes to the resources of meaning-making which language provides to social actors in a community. These resources, which range from simple linguistic units to highly complicated images, perform primary role in shaping and reshaping social beliefs and, thus, the relationships and identities of people. Stuart Hall refers to the same unlimited potentiality of language when he says that meaning-making resources constitute social reality and form knowledge and identity within specific social contexts and power relations (1997, p. 220).

The cultural assimilation, therefore, occurs primarily on the basis of discourse because it encompasses not only the oral or written expression but images as well. Hence, it is a cognitive as well as social phenomenon. Moreover, critical discourse analysts are primarily interested in critically examining the role of language in power relations; however, a discourse analysis brings forth the role of language in any relationship and does not go to the extent of exposing the hidden agenda of the powerful social individuals or groups and taking the stance for the weaker. The current study also aims to explore the role of language in cultural assimilation, mutual 
respect, and coexistence. It emphasizes on adherence to harmony among humans. This study challenges the stereotypical idea of xenophobia, self-centeredness, cultural fanaticism etc. It investigates this concept in Bharati Mukherjee's Jasmine.

Jasmine is an epic saga of young Hindu lass called Jyoti. She pursues her new identity as an immigrant in the United States. The protagonist is from Hasnapur, Punjab and enters into matrimonial alliance with Prakash. His urge for travelling across the world and encountering diverse cultures substantiates him a cosmopolitan. He renovates her identity from Jyoti to Jasmine, which is a prediction of her transformation into multiple identities in future. Unfortunately, her husband dies but she embarks on a ship to cross the borders to America and adapt cultures of the world.

\subsection{Objective of the Research}

This paper aims at meeting the following research objectives by analyzing Mukerjee's Jasmine in the light of the notions of cosmopolitanism and discourse: to examine the extent to which the discourse of a dominant culture magnetizes smaller cultures as a result of which a new cosmopolitan identity emerges.

\subsection{Research Question}

How does the discourse assimilate different cultures into a dominant one to form a cosmopolitan identity?

Nationalism and culture are powerful agents to retain one's own identity. This is an ideology with passionate love which demonstrates positive hostility to outsiders (Nandy, 2006, p. 3502). Movements like Brexit, Anderson's Imagined Communities, Trump's and Modi's neo-nationalism curb the notion of cultural diversity. In global politics, nationalism is one of the most powerful and recognized forces in the world politics. Various nationalities depict themselves and describe their efforts in nationalistic terms. The idea of feminism reverberates through Mukherjee's Jasmine. Moreover, this novel is drenched in the concept of multiculturalism and contains the elements of diaspora.

Cynic Diogenes illustrates the concept of cosmopolitanism in fourth century BC. He proves to be a member of the global community. It is stated that he is asked about his geographical and cultural affiliation. Diogenes responds that he is a citizen of the world (Laertius, 1925, pp. 3-109). The most significant work for the welfare of human is to avoid traditional politics, come together in a circle where all races can become "fellow citizens with saints" (Ephesians, 2:20). Dante Alighieri strongly advocates the precept of universal citizenship in his $D E$ Monarchia (1904, p. 3). He highlights that all human should live in harmony as one community.

Appiah advocates the possibility of a global community in which human beings from different localities enter into a bond of reciprocity notwithstanding their political, cultural, and religious ideology. Globalization erodes the borders and writers express their unique ideas regarding diverse cultural adaptation in the globalized world. Movement becomes a natural phenomenon and paves the way for fluid identities. The boundaries between nations, cultures and societies are irrelevant to a cosmopolitan because to them, all humans are citizens of the same world community.

Cosmopolitan identity is caused by cultural assimilation which itself depends on discourse structure, as it is the dominant discourse that establishes the regime of knowledge and truth in a specific time (Lorenzini, 2015, p. 1). This knowledge and truth form the ideological common sense for the people of that time. Fairclough terms this process of the formation of common sense as "naturalization" (1992, p. 12). He derives this idea for his "naturalization" from Bakhtin's 'dialogical' approach of language which asserts that language and culture undergo 'dialogization' when they become relativized and deprivileged. Undialogized language is dominant or absolute (Fairclough, 2003, p. 42).

Based on this idea, Fairclough suggests five possible scenarios, which include: an openness to or acceptance of or recognition of difference; an exploration of difference; an accentuation of difference; an attempt to resolve or overcome difference; a bracketing of difference; consensus, a normalization and acceptance of differences of power which brackets or suppresses differences of meaning and norms.

However, since the present study views the assimilation of cultures as a positive phenomenon under the idea of cosmopolitanism which believes in the notion of taking keen interest in the beliefs and practices of other cultures to seek and promote mutual respect and peace. Moreover, it focuses on three scenarios of Fairclough, which suit its nature and purpose.

The first scenario, which is an acceptance of difference, is based on intertextuality that Fairclough borrows from Bakhtin, which says that "any utterance is a link in a very complexly organized chain of other utterances with which it enters into one kind of relation to another" (2003, p. 42). According to this scenario, every text appears 
per se as dialogical in one way or another (p. 42). Moreover, this dialogic self emerges from social processes in history. These processes function as stimuli to establish differences among people and societies. It describes the conceptualization of the superiority of a dominant culture over others.

The second scenario is an accentuation of difference. In critical terms, this scenario refers to the conflict which occurs because of the creation of difference. In course of time some discourses achieve superiority and start expressing the intended motives. This is how these discourses establish new identities and ways of being. For example, new socioeconomic formation commonly depends on newly established subjects.

The third scenario, which is an attempt to resolve difference, discusses how, in course of time, discourses are replaced by one another. The process brings forth a new discourse, at a time, which regulates people's way of thinking.

\section{Methodology}

The researcher analyzes the content of Mukherjee's Jasmine from the perspective of cosmopolitanism so far as this cosmopolitan identity is shaped and reshaped by discourse. So, methodologically, the study investigates this notion in the selected text through the joint venture of the theory cosmopolitanism and critical discourse analysis. In critical discourse analysis, the study focuses on Fairclough's concept of naturalization. However, since the study concerns cultural assimilation only to the extent discourse helps in establishing this cosmopolitan identity, it considers only three of his five scenarios, which are an acceptance of difference, accentuation of difference, and an attempt to resolve the difference. The study aligns the concepts of cosmopolitanism and discourse under theoretical triangulation which widens approach of a qualitative researcher to examine a research question from multiple angles to improve research findings (Patton, 2002, p. 453).

\section{Discussion}

\subsection{An Acceptance of Difference}

In context of the study, the first scenario starts with the protagonist's expedition for immigration. Years back, an astrologer foretells that Jasmine, the protagonist of the novel, will adapt to different cultures. Jasmine herself tells us, "Lifetimes ago, under a banyan tree in the village of Hasnapur, an astrologer cupped his ears-his satellite dish to the stars - and foretold my widowhood and exile" (Mukherjee, 1989, p. 3). In the South Asian Indian society, widowhood is a prison as a widow has to live her life with no interaction to other people. Here, in these lines, the juxtaposition of expressions 'widowhood and exile' are oxymoronic. Jasmine has to undergo stages. First, she will be imprisoned and then she will get freedom from the cruel traditions of her society. In addition, the discourse of astrologer, especially that in India, has a mythical significance. However, here, the astrologer's prediction seems myth-breaking. Apparently, he predicts the future course of the protagonist, but his words also ushers her in a new time and society.

Moreover, the words "satellite dish and "stars" are also symbolic in this regard. First, "satellite dish" symbolizes technology, whereas "stars" epitomize farness and freedom. So, the phrase "satellite dish to the stars" implies that Jasmine will travel far away and get freedom with the help of technology. The idea gets materialized when she does leave her conservative society and travel to an advanced culture like America which offers her freedom. She adapts to other cultures and crosses the borders to other countries. Mukherjee makes the idea of her border crossing and acculturation easier through Prakash's death. Jasmine fulfills her husband's dream in the form of journey to the United States. As a postmodern writer, Mukherjee despises the idea of home related to a certain geographical location. Home and culture become a phenomenon of mind for the protagonist. She carries the idea of home in her mind and considers one with the world community.

Similarly, the word 'Dawn, Light, indicate that she possesses the traits of Indian culture and is ready to encounter the new ones. Dawn and light explicate the new human culture which will add beauty to her cosmopolitan personality. It also implies that she comes out of one culture and ventures into new ones because adaptation of other cultures is a great source of knowledge and evidence of coexistence.

Likewise, Jasmine promotes the belief of coexistence, harmony, solidarity, and cultural tolerance through her postmodern fluidity. Jasmine insatiate urge for diverse cultural adaptation is evident through her audacious journey. The astrologer is Mukherjee's strategy to prepare readers for the future journey of Jasmine through continents. This brings to the limelight the mingling of Jasmine with other cultures in the Unites States. Wherever the protagonist moves, she feels herself at home in the surrounding. She finds family like environment in the America and develops strong bond of mutual reciprocity.

Additionally, this acceptance of difference is evident from many other non-semiotic discourse features as well. For instance, dress plays a pivotal role in the representation of any culture. Jasmine's wearing of jeans is her 
acculturation into the American ways of life. Jasmine adapts to the new way of dressing and the new style of walking, as the following lines indicate, "I took out a blue-jean jacket bought for me in Delhi by my brothers... I buttoned up the jacket and sat by the fire... with the first streaks of dawn, my first full American day. I walked out the front drive of the motel to the highway and began my journey, travelling light." (Mukherjee, 1989, pp. 107-108).

\subsection{Accentuation of Difference}

Accentuation of difference is evident in the novel generally in two ways. First, it is evident through the phrases and sentences which seem to reflect the emphasis on the cultural assimilation by the writer herself. For example, she uses the phrases and sentence which imperatively highlight not only the difference of culture but emphasize on the accentuation of this process of the acceptance of difference. For example, she says, “...walk and talk American" (Mukherjee, 1989, p. 134).

Secondly, the accentuation is reflected in the rashness of characters' actions. The characters like the protagonist and her husband seem to expedite their adaptation to the new culture. Jasmine puts every effort to transform into a new identity time and again as a global citizen. Jasmine proves herself to be the member of universal community.

"Escaping an oppressive environment in rural India, the immigrant arrives in the land of opportunity, hoping to make a better life. Finding herself at the margins of American society, due to her immigrant status, Mukherjee's Jasmine does her best to insert herself into the flesh and blood of America, to the point where her body is literally impregnated by that of the white man" (Mukherjee, 1989, p. 73).

Jasmine struggles hard to exhibit harmony and solidarity in the salad bawl like American society and proves to be an integral part of global community. She tries to develop her taste for American food and the act of casting out her traditional apparel deflects the course of her life. The demonstration of her adaptation and interest in the customs of others is evident from her endowment with the guts of excessive movement. Referring to the pace with which Jasmine is accepting the new values, Rao comments, "Jasmine learns to adapt herself to the new surroundings and responds to the speed of transformation, to the fluidity of America character and landscape" (1996, p. 165). As a result, both Gordon and Jasmine appreciate and celebrate the beauty of cultural variation and eliminate the space of such differences. They come close and form a global community where they see exquisiteness in each other. They are kind and their relationship is based on mutual reciprocity. "I got the point he needed to work here, but he did not have to like it. He has sealed his heart when he had left home. His real life was in an unlivable land across oceans. He was a ghost, hanging on.” (Mukherjee, 1989, p. 136).

\subsection{Attempt to Resolve the Difference}

In context of the study, this stage occurs with the determination of the relevant characters to adapt to the new culture and eliminate the old values from their cognition. Jasmine throws the concept of cultural differences to the wind and forms multiple identities with her assimilative quality. Pertinently, she and her husband never look back to their old culture. Nor do they feel any regret. They visit, explore, and experience new cultures and people openly. Jasmine does not hesitate to leave the house of Indian professorji because she is eager to encounter something new apart from her own culture. She embraces every possible experience for assimilation to American culture wholeheartedly. She takes special interest in the practices and beliefs of other cultures which explicates her notion of cosmopolitanism. However, she does not show disregard to the Indian culture when she leaves Punjabi setting in America but avoids things which put hurdles in her assimilation. She feels one with the international human community who believe in human diversity. She molds multiple transformations to something new, positive, and agreeable which is a postmodern characteristic.

Conversely, the protagonist regrets the life she wasted in her affiliation with the old culture. "Flushing was a neighborhood in Jullundhar. I was spiraling into depression behind the fortress of Punjabis ... I felt immured." (Mukherjee, 1989, p. 148). The protagonist unshackles herself from the conventional clutches of her past. She avoids encountering Indian family in the U.S and moves to New York. She is at ease in the new surrounding while discarding some of her practices. Jasmine is uneasy in Vadher's home who is her husband's professor. Her cosmopolitan personality is evident from visiting various places and adjustment. She molds her personality according to the environment and feels oneness with community. She wants everything American and wants to leave behind those things which put hurdles in her way of assimilation. Jasmine shuns her unnecessary Indian restrictions and appreciates cultural diversity. Mukherjee also argues for her American identity. Moreover, she herself expresses that she is an Indian-American writer and that she is neither embarrassed of her Indianness nor misrepresenting it. She says, "But I express about the immigrants' process of taking abode here." She adds that her reader should not define her identity in terms of culture, race etc. but it should be based on what they read 
(Grewal, 1993, p. 95). This expression indicates her integrity with universal community. She does not measure any type of differences but forms a harmonious relationship with humans. "In this apartment of artificially maintained Indianness, I wanted to distance myself from everything Indian, everything Jyoti-like" (Mukherjee, 1989, p. 145).

According to Fairclough's concept of "naturalization", discourses form ideological common sense for people and societies. In the context of study, characters struggle against the established discourses and adapt to the dominant ones. "Prakash did trash some traditions, right from the beginning" (Mukherjee, 1989, p. 6). Prakash gives adequate substantiation regarding his integration with other cultures. He shows respect to the life styles of others and believes in cultural diversity. He enters into matrimonial alliances with Jasmine in the registrar office rather than Hindu traditions. Furthermore, Prakash's attitude illustrates his strong adherence to the idea of human community. Though Jasmine's friend Vimla tells her that their marriage is against Hindu traditions but he does not believe in the purity of culture. This scene is suggestive of Jasmine and Prakash's fluidity as the members of global community. The way they betroth, show obligation to human beings rather than sticking to specific culture.

In addition, Prakash follows the modern and universal way of life while living with his wife alone, not as joint Indian family. He passes away but implants in his wife's mind the concept of encountering diverse cultures through border crossing and assimilation. The protagonist's husband pursues the values of other culture and believes that there is nothing wrong to take interest in the customs of world culture. Their marriage is a metaphoric assimilation to the Western and Christian discourses.

In the same way, Jasmine finds a new name as well. "He wanted to break down the Jyoti as I'd been in Hasnapur and make me a new kind of city woman. To break off the past, he gave me a new name; Jasmine... Jyoti, Jasmine: I shuttled between identities" (Mukherjee, 1989, p. 77). Discursively, the name Jasmine infuses a sense of freedom in her character and predicts her multiple identity. She thinks beyond her Hindu culture and adopts certain traits of other cultures. The couple accepts transformation and cultural diversity with harmony, tolerance, and coexistence.

Jasmine's renovation from Jyote by Prakash implies her swing of integration to the universal culture. The transformation in name substantiates her quest for cultural adaptation and border crossing to the United States. Both husband and wife form new identity according to the global culture and they intend to come out of the purity of culture concept and enjoy the freedom of human diversity in America.

Moreover, these characters adapt to the social resources of discourse of the new culture and utilize these resources as well. For example, Prakash seeks to grab educational and economic opportunities and this brings him closer with the new identity. Cosmopolitan traits are, therefore, evident from his ambition to pursue higher education in the mini world of America. This education significantly enables him to empower Jasmine to embark on the new audacious journey and reassure her place in the world as a global citizen. She defies the fate and wants to do more than the destiny intended. Her husband tactfully makes her mind for assimilation to become world community through names transformation. Jasmine gives vent to her pent up emotions while leaving her hereditary place-Hasnapur for America. The symbolic escape paves a way for boundary crossing, roaming globally, becoming cosmopolitan, adapting diverse cultures and merging into a single community.

The central character substantiates her absolute immersion into the new culture. She also shows respect to Indian traditions but resists it for the sake of experiencing a new culture. Furthermore, Jasmine considers herself an integral part of them as a member of world community. This keen interest in practices of others confirms Jasmine's belonging to human community.

Jasmine encounters an Indian family in Iowa but tries to evade Indian style. She adopts the name Jane which is an ample evidence of submergence into American culture. At the end of the novel, the protagonist becomes American because she has adapted American cultural taste. She observes the routine and pattern of that culture and wants to be among them. Jasmine's expression and attitude verify her global citizenship. Jasmine adapts to multiple identities and forges her character accordingly. This is a sort of Jasmine's rebirth as an immigrant. "I began to fall in love ... with what he presented to me, a professor who served biscuits to a servant, smiled at her and admitted her to the broad democracy of his joking, even when she did not understand it. It seemed entirely American." (Mukherjee, 1989, p. 167).

Moreover, her new identity as Jase, takes another shift in the form of acculturation to the new setting. Mutual conformity is visible from the kind and polite treatment Jasmine gets from her employers. This American family is a symbol of the host society who gleefully accepts the protagonist. This is ample evidence that they accept people from other cultures with their differences. Jasmine's assimilation brings multiple changes in her 
personality including financial independence.

Jasmine's meeting with Taylor culminates into their relationship and consummation of love which symbolizes the resolution of the conflict. They fall in love and throw the cultural differences to the wind. They discuss things and shape each other's ideas and feelings positively. Taylor shows democratic behavior which impresses her. Furthermore, both listen to each other carefully and learn something from their fruitful discussion. Both cultures are open to acceptance and show their adaptive qualities. Tylor's family demonstrates a strong sense of solidarity and coexistence which is evident from their empathetic bond with Jasmine. Parekh considers Jasmine's stay with this family as a fertile phase of her life in the United States and asserts, "This phase in Jasmine's life is most peaceful and comforting, physically, emotionally and psychologically, intellectually, however, it is a period of minute observations of intricate inner deliberations on, and keen involvement in her new surroundings" (Parekh, 1993, p. 113).

She learns many things from the host cultures and Americans also learn from her. She proves loyal towards Taylor when Wylie absconds him. "Jasmine has already, bloomed from a diffident alien with forged documents into adventurous Jase and assimilated the American spirit." (Mukherjee, 1989, p. 178). The protagonist respects the values of others and diverse people live in perfect conformity. It is evident from Taylor's love affairs with Jasmine. Gordon becomes a comfort zone for her and she is treated as a member of the same family. Furthermore, Duff and Wylie are also empathetic towards her and live as fellow citizens. All these characters show a sophisticated, affectionate, and sincere attitude towards one another. There is a two-way acceptance and celebrates cultural diversity with enthusiasm.

The strong relationship between Jasmine and Taylor explicates the mutual reciprocity in the world community. Taylor and other people accept her as integral part of their families because they form a community based on humanity. Duff and Wylie desert him but Jasmine takes special care of him and shows kindness to others as human beings. Their sympathetic relationship is irrespective of race, culture, gender, language etc. They enter into emotional relationship and express warm feelings for each other. Taylor considers her as his dear one and Jasmine regards him as a part of her personality. The psychological and physical relationship between the protagonist and Taylor authenticates their global citizenship because they adhere to the idea of coexistence. Jasmine sticks to the notion of universal citizenship and takes the idea of home in her mind.

Jasmine's experience in the U.S. is immensely pleasant. However, she does not confine herself to her American identity. The fluidity and adaptation of Jasmine is lucid here. She is in constant transformation and sips the honey of cultural flowers. Her American friends have a good relationship with Jasmine and their relationship is based on mutual reciprocity. The saga of her boundary crossing starts when she moves to Florida in a boat. She encounters various people and cultures to become a part of universal community. Jasmine's journey through various countries implicates her urge for joining universal human community. Jasmine appreciates cultural differences and is empathetic towards other traditions. Her inclination towards cultural diversity is evident from her assimilation. She has the ability to absorb various new ways of life and amalgamates into one streak of human community while encountering diversity. "I have a husband for each of the women I have been, Prakash for Jasmine, Taylor for Jase, Bud for Jane, Half Face for Kali." (Mukherjee, 1989, p. 197). The relationship of American people with Jasmine is discernible through mutual recognition, reception, and concern. This openness makes Jasmine a cosmopolitan, an identity which always continues to develop.

\section{Conclusion}

The study investigated that the first scenario of assimilation starts with the protagonist's expedition for immigration. In the outset of the novel, an astrologer prepares Jasmine to embark on her journey. Likewise, the words "satellite dish and "stars" are also symbolic in this regard. First, "satellite dish" symbolizes technology, whereas "stars" embodies farness and freedom. So, the phrase "satellite dish to the stars" implies that Jasmine will travel far away and get liberation with the help of others. Additionally, this acceptance of diversity is evident from many other non-semiotic discourse features as well. For Instance, dress plays a key role in the illustration of any culture. Jasmine's wearing of jeans is her acculturation into the American ways of life.

Accentuation of difference is evident in the novel generally in two ways. First, it is palpable through the phrases and sentences which seem to emphasize on the cultural assimilation by the writer herself. For example, she uses the phrases and sentence which imperatively highlight not only the difference of culture but promote the idea of diverse cultural celebration. Secondly, it is reflected in the prompt actions of the characters themselves. Other characters like the protagonist and her husband seem to expedite their adaptation to the new culture. Jasmine puts every effort to transform into a new identity time and again as a global citizen. Jasmine validates her position as a member of universal community. 
Various characters are determined to adapt new culture and do away with the old values from their cognition. This transformation is expressed by the writers through their discourse. Jasmine throws the concept of cultural differences to the wind and forms multiple identities with her assimilation. Notably, she and her husband never look back to their old culture nor do they feel any regret. They visit, explore, encounter, and experience new cultures and people openly. Jasmine is not hesitant to leave the house of Indian professorji because she is desirous to encounter something unique in the form of new culture. She embraces every possible experience for assimilation to American culture wholeheartedly. Jasmine's notion of cosmopolitanism is evident from her special interest in the practices and beliefs of others.

Jasmine's identity as Jase is another shift. Mutual reciprocity and conformity are visible from the benign and refined treatment Jasmine gets from her employers. American families are a symbol of the host society who gleefully accept human from other culture and their differences in the form of protagonist. Jasmine's assimilation brings multiple changes in her personality including financial independence.

Jasmine's meeting with Taylor culminates into their relationship and consummation of passionate love which symbolizes the resolution of the conflict. The Sexual relationship between Taylor and Jasmine elucidates a shared discreet human community. Taylor and other people accept her as family member because they form a global community where they celebrate the beauty of diversity. His daughter, Duff and wife, Wylie desert him but Jasmine takes special care of him as her family member and acts as a comfort and secured zone for him.

Jasmine's experience in the U.S. is immensely pleasant. However, she never confines herself to her American identity. Jasmine's identity is in constant transformation and sips the honey of cultural flowers. It expresses the lucidity of Jasmine's fluidity and adaptation. The saga of her boundary crossing starts when she moves to Florida in a boat. She encounters various cultures and people and become an agent of cosmopolitanism. Jasmine's journey through various countries and discourse illustrate her cosmopolitan nature. The protagonist is emphatic towards other cultures and appreciates cultural differences. Her inclination towards cultural diversity is evident from her assimilation. She has the aptitude to absorb assorted ways of life and amalgamates into one streak of human community while encountering diversity. "I have a husband for each of the women I have been, Prakash for Jasmine, Taylor for Jase, Bud for Jane, Half Face for Kali." (Mukherjee, 1989, p. 197). The relationship of American people with Jasmine is perceptible through mutual concern, reception, and recognition. This candidness corroborates Jasmine a cosmopolitan, an identity which is in a state of flux and always continues to expand.

\section{References}

Alighieri, D. (1904). Introduction. In M. De (Ed.), Aurelia Henry (pp. 3-5). Cambridge: The Ribersive Press.

Appiah, K. A. (2007). Counter-Cosmopolitans. Cosmopolitanism: Ethics in a World of Strangers (pp. 137-154). New York: W. W. Norton \& Company Inc.

Bakhtin, M. (1981). The Dialogic Imagination (ed. M. Holquist). Austin: University of Texas Press.

Bohman, J., \& Matthias, L. B. (1997). Perpetual Peace: Essays on Kant's Cosmopolitan Ideal. MIT Press.

Brock, G. (2016). Cosmopolitanism: Philosophy. Retrieved July 8, 2015 from https://www.britannica.com/topic/cosmopolitanism-philosophy

Fairclough, N. (1989). Language and Power. London: Longman.

Fairclough, N. (1995). Discourse and Social Change. Cambridge: Polity Press.

Fairclough, N. (1995a). Critical Discourse Analysis. London: Longman.

Fairclough, N. (2003). Analyzing Discourse: Textual Analysis for Social Research. London: Routledge. https://doi.org/10.4324/9780203697078

Foucault, M. (1972). The Archeology of Knowledge. London: Tavistock Publications.

Grewal, G. (1993). Born Again America: Immigrant Conciousness in Jasmine. In S. N. Emmanuel (Ed.), Bharati Mukherjee: Critical Perspectives. New York: Garland.

Hall, S. (1997). Cultural Identity and Diaspora. In R. Jonathan (Ed.), Identity, Culture and difference. London: Lawrence and Wishart.

Laertius, D. (1925). Lives of Eminent Philosophers (Trans. R. D. Hicks, Vol. II). Harvard: Harvard University Press.

Lorenzini, D. (2015). What is a "Regime of Truth"? Le foucaldien, l(1), 1. https://doi.org/10.16995/lefou.2 
Mukherjee, B. (1989). Jasmine. New York: Grove Press.

Nandy, A. (2006). Genuine and Spurious: Mourning Two Early Post-Nationalist Strains. Economic and Political Weekly, 41(32), 3500-3504.

Parekh, P. N. (1993). Telling her Tale: Narrative Voice and Gender Role in Bharati Mukherjee's Jasmine. In S. N. Emmanuel (Ed.), Bharati Mukherjee: Critical Perspectives. New York: Garland.

Patton, M. (2002). Qualitative Research and Evaluation Methods. Thousand Oaks, CA: Sage.

Rao, P. M. (1996). Between Expatriation and Assimilation-A Study of Bharati Mukherjee's Jasmine. In M. K. Bhatnagar (Ed.), Twentieth Century Literature in English (Vol. 2, pp. 162-170). New Delhi: Atlantic Publishers \& Dist.

\section{Copyrights}

Copyright for this article is retained by the author, with first publication rights granted to the journal.

This is an open-access article distributed under the terms and conditions of the Creative Commons Attribution license (http://creativecommons.org/licenses/by/4.0/). 